\title{
The Effect of Ureteral Stent Placement Before Radical Prostatectomy on the Safety of Ureteral Dissection and the Surgeon's Comfort
}

\section{Radikal Prostatektomi Öncesi Üreteral Stent Yerleştirilmesinin Güvenli Üreteral Diseksiyona ve Ameliyat Konforuna Etkisi}

\author{
Fatih Akdemir' ${ }^{1}$ Emrah Okulu², Önder Kayıgil ${ }^{3}$ \\ 'Terme State Hospital, Clinic of Urology, Samsun, Turkiye \\ ${ }^{2}$ Ankara Atatürk Training and Research Hospital, Clinic of Urology, Ankara, Turkiye \\ ${ }^{3}$ Yıldırım Beyazıt University Faculty of Medicine, Department of Urology, Ankara, Turkiye
}

\section{What's known on the subject? and What does the study add?}

It has been reported that placing ureteral stents during robot-assisted laparoscopic radical prostatectomy particularly in patients with a large median lobe after the incision of the anterior bladder neck makes the ureteral dissection procedure safer. We recommend this procedure particularly for patients with a large median lobe, a ureteral orifice that atypically opens closer to the bladder neck, a large ureterocele, a severe ureteral kink, and a history of pelvic radiotherapy or transurethral resection of the prostate.

\begin{abstract}
Objective: This study investigated the role of preoperative ureteral stent placement in reducing the risk of ureteral injury, an intraoperative complication of radical retropubic prostatectomy (RRP), and its contribution to the surgeon's comfort.

Materials and Methods: Open RRP was performed in 66 patients diagnosed with localized prostate cancer in our clinic between 2010 and 2015. The patients were divided into two groups; group $1(n=34)$ underwent surgery without ureteral stent placement and group 2 ( $n=32)$ had surgery following the placement of a ureteral stent. The cases were preoperatively evaluated by suprapubic and transrectal ultrasonography. Perioperative and postoperative complications of all cases were determined. Both groups were assessed in terms of ureteral injury, operative time, and surgeon's comfort.

Results: The mean age of the patients in group 1 and group 2 was $61.12 \pm 5.92$ (50-72) years and $63.58 \pm 6.2$ (51-75) years, respectively. The mean prostate volume was $76.8 \pm 2.41$ and $72.4 \pm 3.53 \mathrm{cc}$ in groups 1 and 2, respectively. The mean operative time was $143.9 \pm 3.06$ minutes in group 1 and $136.8 \pm 2.83$ minutes in group 2. Partial ureteral injury occurred in three patients in group 1 and was repaired intraoperatively. Of these patients, two had previously undergone radiotherapy for prostate cancer and it was difficult to perform prostate dissection intraoperatively. The remaining patient had a history of transurethral resection of the prostate. No ureteral injury was observed in any of the patients in group 2.

Conclusion: Preoperative ureteral stent placement in selected patients can facilitate ureteral dissection and reduce ureteral injury risk.

Keywords: Prostatic neoplasms, prostatectomy, ureter, stents
\end{abstract}

\section{Öz}

Amaç: Bu çalışmada ameliyat öncesi üreteral stent yerleştirilmesinin radikal retropubik prostatektomi (RRP) ameliyatının intraoperatif bir komplikasyonu olan üreter yaralanması riskinin azaltılmasındaki rolü ve cerrahi konfora katkısı değerlendirilmiştir.

Gereç ve Yöntem: 2010-2015 yılları arasında kliniğimizde lokalize prostat kanseri saptanan 66 hastaya açık RRP ameliyatı yapılmıştır. Hastalar iki gruba ayrılmıştır; grup $1(n=34)$ üreteral stent yerleştirilmeden ve grup $2(n=32)$ sistoskopi eşliğinde bilateral üreteral stent yerleştirildikten sonra

Correspondence: Fatih Akdemir MD, Terme State Hospital, Clinic of Urology, Samsun, Turkiye

Phone: +90 5384040494 E-mail: nfatihakdemir@hotmail.com ORCID-ID: orcid.org/0000-0003-1794-211X

Received: 16.06 .2017 Accepted: 28.07 .2017

Cite this article as: Akdemir F, Okulu E, Kayıgil Ö. The Effect of Ureteral Stent Placement Before Radical Prostatectomy on the Safety of Ureteral Dissection and the Surgeon's Comfort. J Urol Surg 2017;4:117-121. 
$\ddot{0 z z}$

opere edilmiştir. Olgular preoperatif olarak suprapubik ve transrektal ultrasonografi ile değerlendirilmiştir. Bütün olguların peroperatif ve postoperatif komplikasyonları tespit edilmiştir. Her iki grup üreteral yaralanma, ameliyat süreleri ve cerrahın ameliyat konforu açısından değerlendirilmiştir.

Bulgular: Bu çalışmadaki grup 1 ve grup 2 hastaların sırasıyla, yaş ortalaması 61,12 $\pm 5,92$ (50-72) ve 63,58 $\pm 6,2$ (51-75) yıl, prostat volümleri

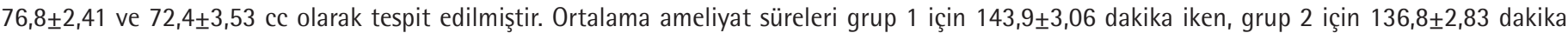
olarak gerçekleşmiştir. Grup 1'deki hastaların üç tanesinde ameliyat sırasında kısmi üreteral yaralanma oluşmuş ve intraoperatif olarak onarılmıştır. $\mathrm{Bu}$ hastalardan iki tanesi daha önce prostat kanseri sebebiyle radyoterapi alan hastalar olup intraoperatif olarak prostat diseksiyonu güçlükle yapılabilmiştir. Bir hastada ise geçirilmiş transüretral prostat rezeksiyonu öyküsü tespit edilmiştir. Grup 2'deki hastaların hiçbirinde üreteral yaralanma oluşmamıştır.

Sonuç: Seçilmiş hastalara ameliyat öncesinde üreteral stent yerleştirilmesi üreteral diseksiyonu kolaylaştırabilir ve üreteral yaralanma riskini azaltabilir.

Anahtar Kelimeler: Prostat tümörleri, prostatektomi, üreter, stentler

\section{Introduction}

Prostate cancer is one of the most common malignancies seen in Turkey as well as across the world and has varying treatment modalities. Radical retropubic prostatectomy (RRP) is a common treatment method for localized prostate cancer. Developed 60 years ago, this operation involves the removal of the entire prostate gland between the bladder and the urethra (1). Approximately 30 years ago, Walsh and Donker (2) developed a neuroprotective technique. Despite all the improvements in the RRP technique, intraoperative and postoperative complications are more frequently seen compared to other operations. Studies have suggested the placement of ureteral stents or use of intravenous indigo carmine to prevent ureteral injury in RRP $(3,4)$. We consider that ureteral stents deployed in selected patients before RRP are an effective method of reducing the risk of intraoperative ureteral injury and contributing to surgeon's comfort.

\section{Materials and Methods}

Open RRP was performed in 66 patients with localized prostate cancer in our clinic between 2010 and 2015. The patients were divided into two groups: group 1 consisted of 34 patients who had open RRP without ureteral stent placement. Group 2 comprised 32 patients who had undergone the same operation following bilateral ureteral stent placement with cystoscopy. Patients who were diagnosed with prostate cancer were preoperatively evaluated by hemogram, biochemistry, chest X-ray, abdominal tomography or magnetic resonance imaging. In cases where necessary, whole-body scintigraphy was performed and the disease was confirmed to be localized. Furthermore, suprapubic and transrectal ultrasonography was undertaken for all patients preoperatively to assess intravesical pathology, prostate volume and median lobe of the prostate. Patients presenting with large median lobe, ureteral orifice that atypically opens closer to the bladder neck, large ureterocele, severe ureteral kink, nodule or hardness on rectal examination and history of pelvic radiotherapy or transurethral resection of the prostate were included in the study. Patients presenting with bladder cancer on ultrasound were excluded from the study. Table 1 shows the demographic characteristics of patients included in the study. All patients were treated with the same technique by the same surgeon. Both groups were evaluated for ureteral dissection and surgeon's comfort during the operation. This study was designed retrospectively and all patients signed an informed consent agreement.

\section{Operation Technique}

Under general anesthesia, cystoscopy was performed on patients of group 2 in the lithotomy position to insert a bilateral ureteral $d-J$ stent. The operation was started with a subclavian median incision in the supine position and bilateral pelvic lymphadenectomy was undertaken to perform complete staging. The endopelvic fascia was opened and completely separated from the prostate levator muscle and made spherical. In patients with large prostates and narrow and deep anatomy of the pelvis, the puboprostatic ligaments were cut. In the remaining patients, the puboprostatic ligaments were left intact. Then, the dorsal venous complex was ligated and cut, and the urethra was removed.

Following the removal of the urethra, the rectourethral fibers, vas deferens, and seminal vesicles were dissected. In young patients presenting with normal findings on rectal examination and low risk, the neurovascular bundle was preserved. The rectal catheter that was inserted preoperatively allowed a safer dissection intraoperatively. Following the separation of the lateral pedicles, the border between the bladder and the prostate was detected and the bladder neck was incised from the anterior to the posterior to separate the prostate from the mesentery; thus, the prostatectomy procedure was completed. After this procedure, the bilateral stents were clearly visible and the intestines around the ureter orifices were confirmed to be intact (Figure 1). In cases where necessary, the bladder neck was narrowed and reconstructed with eversion using the "tennis 
racket" technique. Following the removal of the ureteral stents, vesicoureteral anastomosis was completed with an average of 6 sutures. After a leakage test to confirm that there was no extravasation, the procedure was terminated by closing each layer. A head light and magnification were used during the operation.

\section{Statistical Analysis}

The data was analyzed with the Statistical Package for the Social Sciences v. 16 (SPSS Inc, Illinois, USA). Continuous data was expressed as mean \pm standard deviation. The statistical comparisons of age, prostate volume and operation time were performed by a paired sample t-test. The Kruskal-Wallis $\mathrm{H}$ test was used in the analysis of the demographic characteristics of the patients. A $p$ value of less than 0.05 was considered statistically significant.

\section{Results}

The mean age of the patients in group 1 was $61.12 \pm 5.92$ (5072 ) and those in group 2 was $63.58 \pm 6.2(51-75)$ years. The mean prostate volume in group 1 and group 2 was $76.8 \pm 2.41$ $\mathrm{cc}$ and $72.4 \pm 3.53 \mathrm{cc}$, respectively. The mean operative time was $143.9 \pm 3.06$ in group 1 and $136.8 \pm 2.83$ minutes in group

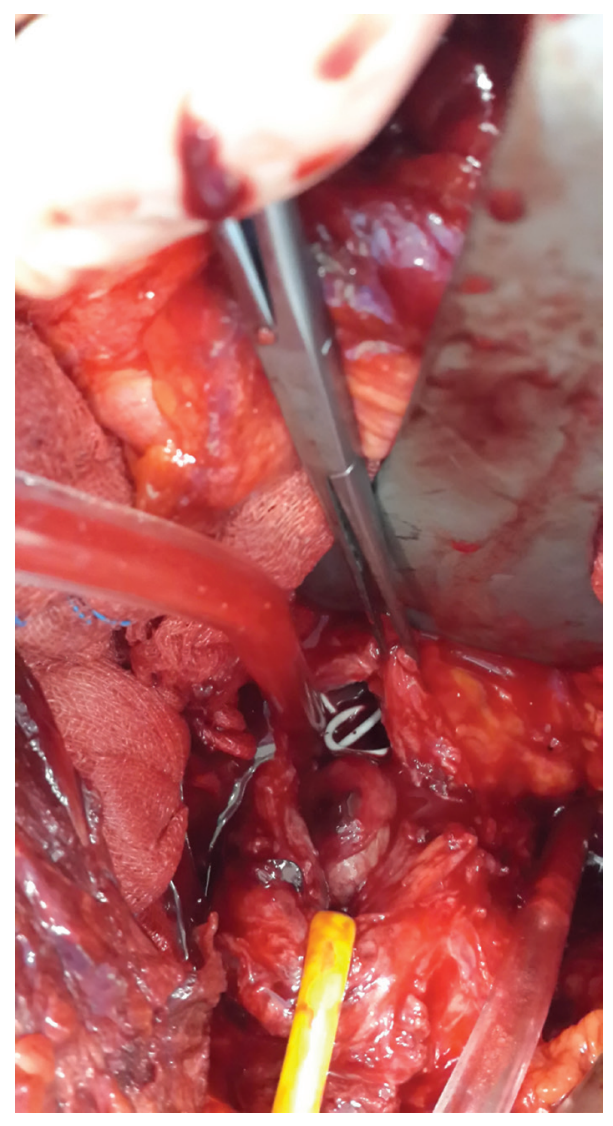

Figure 1. The appearance of a large median lobe (arrow) and ureteral $d-J$ stents during the resection of the bladder neck
2 (Table 2). There was no statistically significant difference between the two groups in terms of age, prostate volume and duration of operation ( $p>0.05)$. Partial ureteral injury occurred in three patients in group 1 during the dissection of the posterior bladder neck. One of these patients had a history of transurethral resection of the prostate. Damage to the left ureteral orifice due to dissection was detected intraoperatively and repaired by implanting it into the bladder mucosa after placing the ureteral $d-J$ stent. The remaining two patients had a history of pelvic radiotherapy, which made it difficult to dissect the tissues resulting in a partial injury to the distal ureter during the dissection of the bladder neck from the posterior. This injury was noticed during the operation and primarily repaired following the insertion of the $d-J$ stent. None of the patients in group 2 presented with any complication. The stents placed in the group 2 patients were removed intraoperatively prior to vesicoureteral anastomosis.

\section{Discussion}

Radical prostatectomy is the only method that has been reported to have an advantage over conservative treatments concerning survival rate, particularly for patients with a life expectancy of

Table 1. The demographic characteristics of the patients

\begin{tabular}{llll}
\hline & $\begin{array}{l}\text { Group } \\
(\mathbf{n = 3 4 )}\end{array}$ & $\begin{array}{l}\text { Group 2 } \\
(\mathbf{n = 3 2 )}\end{array}$ & ${ }^{*} \mathbf{p}$ \\
\hline Large median lobe & 15 & 17 & 0.74 \\
$\begin{array}{l}\text { Atypically located orifices } \\
\text { Bladder tumour }\end{array}$ & 1 & 3 & 0.81 \\
$\begin{array}{l}\text { Ureterocele } \\
\text { Radiotherapy or TUR }{ }^{*} \text { history }\end{array}$ & 5 & - & - \\
$\begin{array}{l}\text { Solitary kidney } \\
\text { Nodule or hardness on rectal }\end{array}$ & - & 1 & 0.76 \\
examination & 7 & 1 & 0.82 \\
\hline *Kruskal-Wallis H test was used in all comparisons & 5 & 0.64 \\
\begin{tabular}{l} 
TUR: Transurethral resection \\
\hline
\end{tabular} & & & \\
\hline
\end{tabular}

Table 2. A comparison of the two groups in terms of age, prostate volume and operation time

\begin{tabular}{llll}
\hline & $\begin{array}{l}\text { Group 1 } \\
(\mathbf{n = 3 4 )}\end{array}$ & $\begin{array}{l}\text { Group 2 } \\
(\mathbf{n = 3 2 )}\end{array}$ & $\mathbf{p}^{*}$ \\
\hline Age (year) & $61.12 \pm 5.92$ & $63.58 \pm 6.2$ & $0.897^{* *}$ \\
Prostate volume (cc) & $76.8 \pm 2.41$ & $72.4 \pm 3.53$ & $0.75^{* *}$ \\
Operation time (minute) & $143.9 \pm 3.06$ & $136.8 \pm 2.83$ & $0.674^{* *}$ \\
\hline${ }^{*}$ Paired sample t-test \\
$\begin{array}{l}\text { **There was no statistically significant difference between the two groups in terms of } \\
\text { age, prostate volume and operation time }\end{array}$ \\
\hline
\end{tabular}


more than 10 years and for those included in the low risk group (5). This procedure has one of the longest learning curves in terms of the anatomical localization of the prostate and the surrounding structures. Radical prostatectomy involves many intraoperative and postoperative complications and its success depends on the use of a good technique. The most important intraoperative complication is hemorrhage, which arises from venous structures and may require transfusion. In different case series, average blood loss has been reported to be $1500 \mathrm{~mL}$ (6). In addition to hemorrhage, rectal injury and obturator nerve injury during pelvic lymphadenectomy may be seen (7).

Another complication that can be seen intraoperatively is ureteral injury, which mostly occurs during dissection of the posterior bladder neck $(3,8)$. Although the incidence changes depending on the experience of the surgeon and the particular case, it has been reported to vary between 0 and $4.7 \%$ (4). It is beyond doubt that preoperative stent placement reduces the risk of ureteral injury particularly in patients with a large median lobe, atypical cases in which the ureteral orifice is too close to the bladder neck, and patients with a history of transurethral resection or pelvic radiotherapy. These stents may be used temporarily and removed at the end of the operation before performing vesicoureteral anastomosis. Another method of preserving ureteral orifices is to use intravenous indigo carmine (4). However, this method has received little attention from researchers.

It cannot be reliably predicted in advance which cases have more risk for ureteral injury. Studies reporting a higher risk in patients with a large median lobe have suggested the use of a temporary ureteral stent or intravenous indigo carmine depending on the surgeon's preference after dissecting the anterior bladder neck in order to prevent ureteral injury during the dissection of the posterior bladder neck in these patients $(3,4)$. In clinical practice, in certain cases, we place a ureteral stent by cystourethroscopy with the patient in the lithotomy position before proceeding to open RRP. Cystourethroscopy offers a more detailed assessment of the urethra and the bladder mucosa and helps identify small bladder pathologies and the localization of ureteral orifices that cannot be detected in preoperative imaging. In the current study, ureteral injury was not observed in any of the patients who underwent surgery after the placement of a $d-J$ stent. We consider that patients with high risk for ureteral injury are those with a large median lobe, a ureter orifice that is atypically close to the bladder neck, a large ureterocele, a severe ureteral kink, and a history of pelvic radiotherapy or transurethral resection of the prostate. In addition, preoperative ureteral stent placement may be an advantage in patients with poor renal function or a solitary kidney. Undertaking this procedure by cystourethroscopy for all cases may be disadvantageous in terms of cost. However, placement of a ureteral stent in the described cases would not only facilitate surgery and allow a safer dissection but may also prevent morbidity due to ureteral injury and reduce additional tests and treatment cost for patients.

In open RRP, after dissecting the bladder neck, surgeons try to monitor ureteral orifices and urine jet, however, observing these structures with the naked eye is both troublesome and extends the duration of the procedure. Ureteral stents placed preoperatively not only reduce the risk of ureteral injury during dissection and allow safer dissection, but also demonstrate ureteral orifices immediately after the dissection of the bladder neck and prevent the prolongation of the operation time. These stents should be removed after placing vesicoureteral anastomotic sutures. It has been reported that placing ureteral stents during robot-assisted laparoscopic radical prostatectomy particularly in patients with a large median lobe after the incision of the anterior bladder neck makes the ureteral dissection procedure safer (3). However, to the best of our knowledge, there is no study in the literature reporting endoscopic placement of a ureteral stent before open RRP.

\section{Study Limitations}

The limitation of this study is that it is performed in a small number of patients. Prospectively randomized trials with greater numbers of patients may contribute to this issue.

\section{Conclusion}

Ureteral stent placement in open radical prostatectomy is not routinely required. However, it may be useful in selected cases that are at risk for dissection. In RRP, ureteral stent placement by cystourethroscopy makes bladder neck dissection safer and reduces the risk of intraoperative ureteral injury without significantly affecting the operation time. We recommend this procedure particularly for patients with a large median lobe, a ureteral orifice that atypically opens closer to the bladder neck, a large ureterocele, a severe ureteral kink, and a history of pelvic radiotherapy or transurethral resection of the prostate.

\section{Ethics}

Ethics Committee Approval: Ethics committee approval was not applied because of retrospective design.

Informed Consent: Consent form was filled out by all participants.

Peer-review: External and internal peer-reviewed.

\section{Authorship Contributions}

Surgical and Medical Practices: F.A., Ö.K., E.O., Concept: F.A., E.O., Ö.K., Design: F.A., E.O., Ö.K., Data Collection or Processing: F.A., E.O., Ö.K., Analysis or Interpretation: F.A., E.O., Ö.K., Literature Search: F.A., E.O., Ö.K., Writing: F.A., E.O., Ö.K. 
Conflict of Interest: No conflict of interest was declared by the authors.

Financial Disclosure: The authors declared that this study received no financial support.

\section{References}

1. Memmelaar J. Total prostatovesiculectomy; retropubic approach. J Urol 1949;62:340-348.

2. Walsh PC, Donker PJ. Impotence following radical prostatectomy: insight into etiology and prevention. J Urol 1982;128:492-497.

3. El Douaihy Y, Tan GY, Dorsey PJ, Jhaveri JK, and Tewari AK. Double-pigtail stenting of the ureters: technique for securing the ureteral orifices during robot-assisted radical prostatectomy for large median lobes. J Endourol 2009;23:1975-1977.

4. Schlenker B, Gratzke C, Seitz M, Von Walter P, Tilki D, Reich O, Zaak D, Stief CG, Bader MJ. Minimizing complications during retropubic radical prostatectomy - Is ureteral stenting necessary? Eur J Med Res 2010;15:121123.

5. Bill-Axelson A, Holmberg L, Filen F, Ruutu M, Garmo H, Busch C, Nordling S, Haggman M, Andersson SO, Bratell S, Spangberg A, Palmgren J, Adami HO, Johansson JE; Scandinavian Prostate Cancer Group Study Number 4. Radical prostatectomy versus watchful waiting in localized prostate cancer: the Scandinavian prostate cancer group-4 randomized trial. J Natl Cancer Inst 2008;100:1144-1154.

6. Catalona WJ, Carvalhal GF, Mager DE, Smith DS. Potency, continence and complication rates in 1,870 consecutive radical retropubic prostatectomies. J Urol 1999;162:433-438.

7. Shekarriz B, Upadhyay J, Wood DP. Intraoperative, perioperative, and long-term complications of radical prostatectomy. Urol Clin North Am 2001;28:639-653.

8. Teber D, Gözen AS, Cresswell J, Canda AE, Yencilek F, Rassweiler J. Prevention and management of ureteral injuries occurring during laparoscopic radical prostatectomy: the Heilbronn experience and a review of the literature. World J Urol 2009;27:613-618. 